\title{
EFFECT OF MANAGEMENT SYSTEMS AND COVER CROPS ON ORGANIC MATTER DYNAMICS OF SOIL UNDER VEGETABLES $^{(1)}$
}

\author{
Rodrigo Fernandes de $\operatorname{Souza}^{(2)}$, Cícero Célio de Figueiredo ${ }^{(3)}$, Nuno Rodrigo Madeira ${ }^{(4)} \&$ \\ Flávia Aparecida de Alcântara ${ }^{(5)}$
}

\begin{abstract}
SUMMARY
Vegetable production in conservation tillage has increased in Brazil, with positive effects on the soil quality. Since management systems alter the quantity and quality of organic matter, this study evaluated the influence of different management systems and cover crops on the organic matter dynamics of a dystrophic Red Latosol under vegetables. The treatments consisted of the combination of three soil tillage systems: no-tillage (NT), reduced tillage (RT) and conventional tillage (CT) and of two cover crops: maize monoculture and maizemucuna intercrop. Vegetables were grown in the winter and the cover crops in the summer for straw production. The experiment was arranged in a randomized block design with four replications. Soil samples were collected between the crop rows in three layers $(0.0-0.05,0.05-0.10$, and $0.10-0.30 \mathrm{~m})$ twice: in October, before planting cover crops for straw, and in July, during vegetable cultivation. The total organic carbon (TOC), microbial biomass carbon (MBC), oxidizable fractions, and the carbon fractions fulvic acid $\left(\mathrm{C}_{\mathrm{FA}}\right)$, humic acid $\left(\mathrm{C}_{\mathrm{HA}}\right)$ and humin $\left(\mathrm{C}_{\mathrm{HUM}}\right)$ were determined. The main changes in these properties occurred in the upper layers (0.0-0.05 and 0.05-0.10 m) where, in general, TOC levels were highest in NT with maize straw. The MBC levels were lowest in CT systems, indicating sensitivity to soil disturbance. Under mucuna, the levels of $\mathrm{C}_{\mathrm{HA}}$ were lower in $\mathrm{RT}$ than NT systems, while the $\mathrm{C}_{\mathrm{FA}}$ levels were lower in $\mathrm{RT}$ than $\mathrm{CT}$. For vegetable production, the $\mathrm{C}_{\mathrm{HUM}}$ values were lowest in the $0.05-0.10 \mathrm{~m}$ layer under CT. With regard to the oxidizable fractions, the tillage systems differed only in the most labile $\mathrm{C}$ fractions, with higher levels in NT than CT in the 0.0-0.05 m layer in both summer and winter, with
\end{abstract}

(1) Received for publication on April 24, 2013 and approved on January 13, 2014.

(2) MSc. in Agronomy, Universidade de Brasília - UnB. Caixa Postal 04508. CEP 70910-970 Brasília (DF). E-mail: rodrigofunb@gmail.com

(3) Professor, Faculdade de Agronomia e Medicina Veterinária - UnB. E-mail: cicerocf@unb.br

(4) Researcher, Embrapa Hortaliças. Km 09, Rodovia BR 060. Caixa Postal 218. CEP 70359970 Brasília (DF). E-mail: nuno.madeira@embrapa.br

(5) Researcher, Embrapa Arroz e Feijão. Rodovia GO-462, km 12, Zona Rural. Caixa Postal 179. CEP 75375000 Santo Antônio de Goiás (GO). E-mail: flavia.alcantara@embrapa.br 
no differences between these systems in the other layers. The cabbage yield was not influenced by the soil management system, but benefited from the mulch production of the preceding maize-mucuna intercrop as cover plant.

Index terms: organic carbon, oxidizable fractions, microbial biomass, humic fractions.

\title{
RESUMO: INFLUENNCIA DE SISTEMAS DE MANEJO E COBERTURA VEGETAL NA DINÂMICA DA MATÉRIA ORGÂNICA DE SOLO CULTIVADO COM HORTALIÇAS
}

\begin{abstract}
A produção de hortaliças em sistemas conservacionistas tem crescido no Brasil com reflexos positivos na qualidade do solo. Considerando que os sistemas de manejo alteram a quantidade e a qualidade da matéria orgânica, este trabalho teve por objetivo avaliar a influência de diferentes sistemas de manejo e cobertura vegetal na dinâmica da matéria orgânica de um Latosssolo Vermelho distrófico, cultivado com hortaliças. Os tratamentos avaliados consistiram na combinação de três sistemas de manejo de solo: plantio direto (PD); plantio com preparo reduzido (PPR); e preparo convencional (PC), e duas coberturas vegetais: milho e consórcio milho e mucuna. No inverno, foram cultivadas hortaliças; e no verão, cobertura vegetal para palhada. O delineamento experimental utilizado foi de blocos ao acaso com quatro repetições. As amostras de solo foram coletadas na entrelinha de cultivo da hortaliça em três profundidades (0,0-0,05; 0,05-0,10 e 0,10-0,30 m), em duas épocas de amostragem: em outubro, antes do plantio das culturas para formação de palhada; e em julho, durante o cultivo da hortaliça. Foram determinados o carbono orgânico total (COT), o carbono da biomassa microbiana $(C B M)$, das frações oxidáveis, e o carbono das frações ácido fúlvico $\left(C_{A F}\right)$, ácido húmico $\left(C_{A H}\right)$ e humina $\left(C_{H U M}\right)$. As principais alterações nos atributos avaliados ocorreram nas profundidades mais superficiais (0,0-0,05 e 0,05-0,10 m), onde, de maneira geral, o PD com palhada de milho se destacou com os maiores teores de COT. Os valores do $C B M$ foram menores nos sistemas de PC, evidenciando-se sensivel ao revolvimento do solo. Os sistemas com preparo reduzido foram inferiores ao plantio direto com mucuna nos teores de $C_{A H}$ e ao preparo convencional nos teores de $C_{A F}$. O uso do preparo convencional do solo para produção de hortaliças apresentou os menores valores de $C_{H U M}$ na profundidade de 0,05-0,10 m. Entre as frações oxidáveis, os sistemas de preparo se diferenciaram somente nas frações mais lábeis do C, sendo o PD superior ao PC na profundidade 0,0-0,05 $\mathrm{m}$, tanto no verão quanto no inverno, não havendo diferenças entre esses sistemas nas demais profundidades. A produtividade de repolho não foi influenciada pelo sistema de manejo do solo, mas foi beneficiada pelo uso do consórcio milho + mucuna como planta de cobertura formadora de palhada.
\end{abstract}

Termos de indexação: carbono orgânico, frações oxidáveis, biomassa microbiana, frações húmicas.

\section{INTRODUCTION}

A number of management and crop systems are being used in the Cerrado (savanna-like vegetation) region of Brazil, with impacts on soil components, above all on the compartments of soil organic matter (SOM). In conventional systems, the soil acts as a source of carbon (C) to the atmosphere (Bayer et al., 2004), whereas no-tillage (NT) is an alternative to minimize impacts on the soil by different forms of land use. The basic principles of NT lead to a reduction in $\mathrm{CO}_{2}$ emissions to the atmosphere and increase the $\mathrm{C}$ and $\mathrm{N}$ stocks in the soil (Carvalho et al., 2010).

The importance of SOM to improve the soil chemical, physical and biological properties is widely recognized. Aside from the evaluation of the contents, several analytical procedures were developed in recent years to understand the functions of the SOM fractions. Among these, the soil microbial biomass is responsible for biochemical and biological processes in the soil and substantially affected by the environmental conditions (Balota et al., 2008). When the organic residue input to the soil is increased and the amount of roots is large, the microbial biomass is stimulated, increasing the microbial population (Souza et al., 2010).

Aside from microbial $\mathrm{C}$, the humified fractions of SOM represent an important compartment that performs several beneficial functions in the soil. Chemical fractionation is one of the oldest analytical procedures for SOM analysis. The humic fractions have been used as soil quality indicators, due to the strong interaction of humic substances with mineral materials and their relationship with soil 
management (Fontana et al., 2006). Several studies have reported the influence of agricultural management systems on the humic fractions (Barreto et al., 2008; Portugal et al., 2008; Santana et al., 2011). The use of no-tillage, for example, preserves organic C in all humic fractions (Rosa et al., 2008). On the other hand, in systems with soil tillage, the fulvic acids and humin contents tend to increase and humic acids tend to decrease (Cunha et al., 2001).

To deepen the understanding about the stability level of $\mathrm{C}$, the organic matter can be fractionated according to the susceptibility degree to oxidation in acidic media. In this sense, a procedure that divides SOM carbon in four fractions (F1, F2, F3, and F4) was proposed by Chan et al. (2001). The most easily oxidized fractions F1 and F2 are associated with nutrient availability and macroaggregate formation (Blair et al., 1995; Chan et al., 2001). The fractions F3 and F4 however are related to compounds with higher chemical stability and molar mass, originating from decomposition and humification (Stevenson, 1994).

Characteristics related to lability, the ease of oxidation and the amount of microbial biomass activity, along with yield data of agriculturally relevant crops, can serve as tools to assess crop sustainability from the point of view of soil preservation.

There is a growing demand for vegetable production on a scale parallel to the population growth. To meet this need, vegetable production on a larger scale must be accompanied by management systems that enable production increase combined with production sustainability, preserving the soil quality. In grain production, for example, conservation tillage has been widely used. But for the production of vegetable crops, few studies have addressed this type of management and its influence on vegetable production.

Accordingly, this study aimed to evaluate the influence of different management systems and cover crops on the dynamics of organic matter in a dystrophic Red Latosol under vegetables.

\section{MATERIAL AND METHODS}

The experiment was conducted on an experimental field of Embrapa Hortaliças, Brasilia, at 997.6 m asl. The climate is Cwa, according to Köppen's classification, e.g., humid temperate with dry winters and hot summers. The experimental area was classified as clayey Oxisol (Santos et al., 2006).

The experimental area was originally covered by dry grassland vegetation (Cerrado) and used for vegetable cultivation under conventional tillage (CT) since the 1980s. The experiment was installed in December 2007 in a completely randomized block design with four replications. The plots $(12 \times 9 \mathrm{~m})$ were evaluated in four replications, in a $3 \times 2$ factorial design. The treatments consisted of three soil management systems (no-tillage - NT; reduced tillage - RT; and conventional tillage - CT) and two plant cover types for straw supply (maize monoculture - M and maize-Mucuna aterrima intercrop -MM), grown in the summer (December to April) and vegetables planted in the winter. The crops, plant stand and fertilizers used from 2007 to 2011 are listed in table 1 and the chemical properties of the studied soil, sampled prior to the experiment, in table 2 .

\section{Times and depths of soil sampling}

The composite samples were collected at depths of 0.0-0.05, 0.05-0.10 and 0.10-0.30 $\mathrm{m}$, in two samplings. The first sampling was performed in October 2011, at the beginning of the rainy season considered "summer", at the beginning of the fifth experimental year, and the second in July 2012 at the end of the fifth year, in the stage of full development (cabbagehead formation), considered "winter".

For each composite sample, two subsamples were randomly collected between the crop rows. The samples were homogenized, placed in labeled plastic bags and stored in a cold chamber at $4{ }^{\circ} \mathrm{C}$ for microbiological analyses. Part of this material was air-dried, ground and all soil was sieved $(<0.5 \mathrm{~mm})$ for the other analyses.

\section{Crop management}

Maize was sown on all plots on December 08, 2011, in rows spaced $0.80 \mathrm{~m}$ apart and five seeds per meter. Phosphate fertilizer was applied $\left(100 \mathrm{~kg} \mathrm{ha}^{-1} \mathrm{P}_{2} \mathrm{O}_{5}\right)$. The commercial hybrid Ag1045 of the company Agroceres ${ }^{\circledR}$ was used with a population of 55,000 plants $\mathrm{ha}^{-1}$. In the maize-mucuna intercrop treatments, the species were sown in a row spacing of $1.60 \mathrm{~m}$ and two seeds per meter, 30 days after maize sowing. In mid-March 2012, the MM intercrop was harvested with a straw crushing-shredding device (Triton $\left.{ }^{\circledR}\right)$, leaving the straw on the ground. The CT plots were tilled (plowing and disking) and the RT plots tilled once with a leveling disc harrow, only for surface incorporation of the crop residues to a maximum depth of $0.05 \mathrm{~m}$.

On May 16, 2012, cabbage seedlings of cv. Astrus

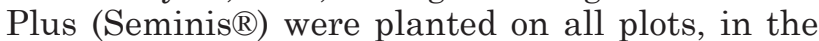
treatments mentioned above. A spacing of $0.70 \times$ $0.60 \mathrm{~m}$ was used with 23,089 plants ha-1 on a total plot area of $108 \mathrm{~m}^{2}(12 \times 9 \mathrm{~m})$. At planting, fertilization consisted of $100 \mathrm{~kg} \mathrm{ha}^{-1} \mathrm{P}_{2} \mathrm{O}_{5}$. Sidedressing was performed with ammonium sulfate 20 and 40 days after transplanting at two fertilization rates (6 and $10 \mathrm{~g} /$ plant, respectively). Other cultural practices were performed according to the official crop-specific recommendations (Filgueira, 2000).

Ninety days after transplanting, 20 cabbage plants per plot were harvested. The harvested plants per treatment were weighed and the cabbage heads 
Table 1. History of crops, plant density and fertilization

\begin{tabular}{|c|c|c|c|c|c|}
\hline \multirow{2}{*}{ Growing season } & \multicolumn{2}{|c|}{ Crop } & \multirow{2}{*}{$\begin{array}{c}\text { Stand } \\
\text { Plant ha }{ }^{-1}\end{array}$} & \multicolumn{2}{|c|}{ Fertilization } \\
\hline & Summer & Winter & & At planting & Sidedressing \\
\hline $2007 / 2008$ & $\begin{array}{c}\text { maize } \\
\text { maize }+ \text { mucuna }\end{array}$ & Onion & 400,000 & $\begin{array}{c}600 \mathrm{~kg} \mathrm{ha}^{-1} \\
\text { N-P-K fertilizer 04-30-16 }\end{array}$ & $\begin{array}{c}400 \mathrm{~kg} \mathrm{ha}^{-1} \\
\text { Ammonium sulphate }\end{array}$ \\
\hline $2008 / 2009$ & $\begin{array}{c}\text { maize } \\
\text { maize }+ \text { mucuna }\end{array}$ & Cabbage & 23,089 & $\begin{array}{l}1250 \mathrm{~kg} \mathrm{ha}^{-1} \text { Single } \\
\text { superphosphate }+250 \mathrm{~kg} \mathrm{ha}^{-1} \\
\text { Ammonium sulphate }\end{array}$ & $\begin{array}{c}500 \mathrm{~kg} \mathrm{ha}^{-1} \\
\text { Ammonium sulphate }\end{array}$ \\
\hline $2009 / 2010$ & $\begin{array}{c}\text { maize } \\
\text { maize }+ \text { mucuna }\end{array}$ & Broccoli & 23,089 & $\begin{array}{c}1000 \mathrm{~kg} \mathrm{ha}^{-1} \text { Single } \\
\text { superphosphate }+250 \mathrm{~kg} \mathrm{ha}^{-1} \\
\text { Ammonium sulphate }\end{array}$ & $\begin{array}{c}500 \mathrm{~kg} \mathrm{ha}^{-1} \\
\text { Ammonium sulphate }\end{array}$ \\
\hline $2010 / 2011$ & $\begin{array}{c}\text { maize } \\
\text { maize + mucuna }\end{array}$ & Pumpkin & 3,333 & $\begin{array}{l}300 \mathrm{~kg} \mathrm{ha}^{-1} \text { Single } \\
\text { superphosphate }\end{array}$ & $\begin{array}{c}150 \mathrm{~kg} \mathrm{ha}^{-1} \\
\text { Ammonium sulphate }\end{array}$ \\
\hline $2011 / 2012$ & $\begin{array}{c}\text { maize } \\
\text { maize }+ \text { mucuna }\end{array}$ & Cabbage & 23,089 & $\begin{array}{l}556 \mathrm{~kg} \mathrm{ha}^{-1} \text { Single } \\
\text { superphosphate }\end{array}$ & $\begin{array}{c}370 \mathrm{~kg} \mathrm{ha}^{-1} \\
\text { Ammonium sulphate }\end{array}$ \\
\hline
\end{tabular}

Table 2. Chemical properties of the studied soil

\begin{tabular}{|c|c|c|c|}
\hline \multirow{2}{*}{ Property $^{(1)}$} & \multicolumn{3}{|c|}{ Layer } \\
\hline & $0.0-0.05 \mathrm{~m}$ & $0.05-0.10 \mathrm{~m}$ & $0.10-0.30 \mathrm{~m}$ \\
\hline $\mathrm{pH}\left(\mathrm{H}_{2} \mathrm{O}\right)$ & $5.4 \pm 0.3^{(2)}$ & $5.5 \pm 0.3$ & $5.5 \pm 0.3$ \\
\hline $\mathrm{P}\left(\mathrm{mg} \mathrm{kg}{ }^{-1}\right)$ & $77.8 \pm 36.1$ & $75.3 \pm 23.6$ & $54.1 \pm 27.2$ \\
\hline $\mathrm{K}\left(\mathrm{mg} \mathrm{kg}{ }^{-1}\right)$ & $125.9 \pm 18.4$ & $103.7 \pm 15.2$ & $93.3 \pm 16.0$ \\
\hline $\mathrm{Na}\left(\mathrm{mg} \mathrm{kg}{ }^{-1}\right)$ & $7.9 \pm 0.8$ & $8.1 \pm 0.6$ & $8.2 \pm 0.7$ \\
\hline $\mathrm{Ca}^{2+}\left(\mathrm{cmol}_{\mathrm{c}} \mathrm{kg}^{-1}\right)$ & $9.1 \pm 1.2$ & $5.6 \pm 1.2$ & $5.1 \pm 1.2$ \\
\hline $\mathrm{Mg}^{2+}\left(\mathrm{cmol}_{\mathrm{c}} \mathrm{kg}^{-1}\right)$ & $2.6 \pm 0.9$ & $1.84 \pm 0.4$ & $1.7 \pm 0.34$ \\
\hline $\mathrm{Al}^{3+}\left(\mathrm{cmol}_{\mathrm{c}} \mathrm{kg}^{-1}\right)$ & $0.05 \pm 0.05$ & $0.05 \pm 0.06$ & $0.07 \pm 0.05$ \\
\hline $\mathrm{H}+\mathrm{Al}\left(\mathrm{cmol}_{\mathrm{c}} \mathrm{kg}^{-1}\right)$ & $7.7 \pm 1.2$ & $7.41 \pm 1.1$ & $7.0 \pm 1.34$ \\
\hline
\end{tabular}

evaluated for marketable quality, to finally estimate the yield $\left(\mathrm{kg} \mathrm{ha}^{-1}\right)$.

\section{Laboratory analysis}

The microbial biomass carbon (MBC) was determined by the method of microwave irradiationextraction, described by Ferreira et al. (1999), by which the soil samples were irradiated in a microwave oven for $137 \mathrm{~s}$. The MBC was extracted with a $0.5 \mathrm{~mol} \mathrm{~L}^{-1}$ $\mathrm{K}_{2} \mathrm{SO}_{4}$ solution. The amount of $\mathrm{MBC}$ was determined by the difference between $\mathrm{C}$ extracted from irradiated and non-irradiated soil samples, using a correction factor $\left(\mathrm{k}_{\mathrm{C}}\right)$ of 0.33 (Mendonça \& Matos, 2005).

The oxidizable organic matter fractions were determined according to the procedure proposed by Chan et al. (2001) and modified by Rangel et al. (2008), summarized as: samples of $0.5 \mathrm{~g}$ of fine air-dried soil were placed in $250 \mathrm{~mL}$ Erlenmeyer flasks, adding $10 \mathrm{~mL}$ of $0.167 \mathrm{~mol} \mathrm{~L}^{-1} \mathrm{~K}_{2} \mathrm{Cr}_{2} \mathrm{O}_{7}$ and $2.5 ; 5 ; 10$; and $20 \mathrm{~mL}$ of $\mathrm{H}_{2} \mathrm{SO}_{4}$, corresponding, respectively, to final
$\mathrm{H}_{2} \mathrm{SO}_{4}$ concentrations of $3,6,9$, and $12 \mathrm{~mol} \mathrm{~L}^{-1}$. Oxidation without external heat source was carried out and the extracts were titrated with a solution of $0.4 \mathrm{~mol} \mathrm{~L} \mathrm{~L}^{-1} \mathrm{Fe}\left(\mathrm{NH}_{4}\right)_{2}\left(\mathrm{SO}_{4}\right)_{2} \cdot 6 \mathrm{H}_{2} \mathrm{O}$, using phenanthroline as indicator. The SOM was separated in four fractions, with decreasing degrees of oxidation: Fraction 1 (F1): C oxidized by $\mathrm{K}_{2} \mathrm{Cr}_{2} \mathrm{O}_{7}$ with $3 \mathrm{~mol} \mathrm{~L}^{-1}$ $\mathrm{H}_{2} \mathrm{SO}_{4}$;

Fraction 2 (F2): difference between $\mathrm{C}$ oxidized by $\mathrm{K}_{2} \mathrm{Cr}_{2} \mathrm{O}_{7}$ with 6 and $3 \mathrm{~mol} \mathrm{~L}^{-1} \mathrm{H}_{2} \mathrm{SO}_{4}$;

Fraction 3 (F3): difference between $\mathrm{C}$ oxidized by $\mathrm{K}_{2} \mathrm{Cr}_{2} \mathrm{O}_{7}$ with 9 and $6 \mathrm{~mol} \mathrm{~L}^{-1} \mathrm{H}_{2} \mathrm{SO}_{4}$;

Fraction 4 (F4): difference between $\mathrm{C}$ oxidized by $\mathrm{K}_{2} \mathrm{Cr}_{2} \mathrm{O}_{7}$ with 12 and $9 \mathrm{~mol} \mathrm{~L}^{-1} \mathrm{H}_{2} \mathrm{SO}_{4}$.

The $\mathrm{C}$ of the humic fractions of organic matter (fulvic acid, humic acid and humin) was determined by the method of Mendonça \& Matos (2005).

\section{Statistical analyses}

The data were subjected to analysis of variance and means compared by the Tukey test $(p<0.05)$, using the SAS statistical software (SAS, 2002).

\section{RESULTS AND DISCUSSION}

The TOC concentrations ranged from $14.7 \mathrm{~g} \mathrm{~kg}^{-1}$ in $\mathrm{CT}_{\mathrm{MM}}$ in the $10-30 \mathrm{~cm}$ layer to $25.6 \mathrm{~g} \mathrm{~kg}^{-1}$ in $\mathrm{NT}_{\mathrm{MM}}$ in the surface layer $0.0-0.05 \mathrm{~m}$, both in the winter, with a gradual decrease with increasing depth (Table 3). In both sampling periods (summer and winter) the TOC values were higher in $\mathrm{NT}_{\mathrm{MM}}$ than in $\mathrm{CT}_{\mathrm{M}}$ and $\mathrm{CT}_{\mathrm{MM}}$ in the surface layer (Table 3). Also in this layer, considering only the winter, the TOC levels were higher in the two systems under no-tillage 
$\left(\mathrm{NT}_{\mathrm{MM}}\right.$ and $\left.\mathrm{NT}_{\mathrm{M}}\right)$ than $\mathrm{CT}$. These results suggest that the supply of materials in different quantities and qualities contributes to increase the soil $\mathrm{C}$ content, as laid out by Guareschi et al. (2012). It was also observed that the maize-mucuna intercrop promoted increases in surface TOC levels, which persisted in the different seasons. This is a positive characteristic for the production of vegetables in different seasons. As reported by Amado et al. (2001), the use of mucuna in no-tillage maize promotes an increase in organic $\mathrm{C}$ stocks. However, in this study, despite the use of this intercrop, annual soil tillage induced a reduction in organic matter compared to no-tillage in the same intercrop.

Under reduced tillage, the TOC levels were intermediate between NT and CT in both sampling periods in the 0.0-0.05 m layer. In the 0.05-0.10 m layer, only $\mathrm{CT}_{\mathrm{M}}$ had higher TOC levels than $\mathrm{RT}_{\mathrm{MM}}$ in summer (Table 3). This may have been due to the effect of plowing, incorporating organic residues in deeper layers. Similar results were found by Pereira et al. (2010), who reported the highest TOC levels at this depth in $\mathrm{CT}$, under maize and soybean.

In the 0.10-0.30 $\mathrm{m}$ layer, no differences were observed in TOC concentrations between the management systems in both seasons (Table 3). These results demonstrated that the changes caused by the management systems in the TOC levels were restricted to the surface layer $(0.0-0.05$ and $0.05-0.10 \mathrm{~m})$ with little change in deeper layers, as observed by Pereira et al. (2010) for soybean and maize and by Menezes \& Silva (2008) for potato after six years of organic management.

When only the soil tillage system was evaluated regardless of the cover crop in both sampling times (summer and winter), differences were restricted to the 0.0-0.05 m layer, in which the TOC levels were higher in NT than RT in summer and than $\mathrm{CT}$ in winter (Figure 1a,b).

The MBC levels ranged from 146.78 to $438.27 \mathrm{mg} \mathrm{kg}^{-1}$ with a gradual decrease with increasing depth (Table $3)$. In general, in relation to the MBC content, the greatest differences between systems were found in the summer season at both depths. In winter, only $\mathrm{RT}_{\mathrm{M}}$ was superior to $\mathrm{RT}_{\mathrm{MM}}$ in the 0.0-0.05 m layer, with no differences between other systems and depths.

In winter sampling, differences between the systems were only observed in the 0.0-0.05 m layer, with highest $\mathrm{C}$ content in $\mathrm{RT}_{\mathrm{MM}}$ and $\mathrm{NT}_{\mathrm{MM}}$, as also observed in the first sampling, due to the input of diversified organic material. No statistical differences were found in the other studied layers.

Table 3. Total organic carbon (TOC), microbial biomass carbon (MBC) and microbial quotient ( $q$ Mic) in soil under different tillage systems and cover crops, in three layers and sampling times

\begin{tabular}{|c|c|c|c|c|c|c|}
\hline \multirow{2}{*}{ System $^{(1)}$} & \multicolumn{2}{|c|}{$0.0-0.05 \mathrm{~m}$} & \multicolumn{2}{|c|}{$0.05-0.10 \mathrm{~m}$} & \multicolumn{2}{|c|}{$0.10-0.30 \mathrm{~m}$} \\
\hline & Summer & Winter & Summer & Winter & Summer & Winter \\
\hline & & & TOC $\left(\mathrm{g} \mathrm{k}^{2}\right.$ & & & \\
\hline $\mathrm{NT}_{\mathrm{M}}$ & $21.3 \mathrm{AB}$ & $23.3 \mathrm{~A}$ & $18.4 \mathrm{AB}$ & $17.7 \mathrm{~A}$ & $15.7 \mathrm{~A}$ & $15.4 \mathrm{~A}$ \\
\hline $\mathrm{NT}_{\mathrm{MM}}$ & $23.3 \mathrm{~A}$ & $25.6 \mathrm{~A}$ & $17.8 \mathrm{AB}$ & $17.9 \mathrm{~A}$ & $14.8 \mathrm{~A}$ & $15.1 \mathrm{~A}$ \\
\hline $\mathrm{RT}_{\mathrm{M}}$ & $22.5 \mathrm{AB}$ & $21.8 \mathrm{~B}$ & $17.1 \mathrm{AB}$ & $18.1 \mathrm{~A}$ & $15.2 \mathrm{~A}$ & $16.4 \mathrm{~A}$ \\
\hline $\mathrm{RT}_{\mathrm{MM}}$ & $21.9 \mathrm{AB}$ & $22.8 \mathrm{AB}$ & $16.4 \mathrm{~B}$ & $17.5 \mathrm{~A}$ & $14.8 \mathrm{~A}$ & $14.9 \mathrm{~A}$ \\
\hline $\mathrm{CT}_{\mathrm{M}}$ & $20.0 \mathrm{~B}$ & $20.1 \mathrm{BC}$ & $19.4 \mathrm{~A}$ & $18.0 \mathrm{~A}$ & $16.0 \mathrm{~A}$ & $15.1 \mathrm{~A}$ \\
\hline \multirow[t]{2}{*}{$\mathrm{CT}_{\mathrm{MM}}$} & $19.8 \mathrm{~B}$ & $19.0 \mathrm{C}$ & $18.5 \mathrm{AB}$ & $17.9 \mathrm{~A}$ & $15.8 \mathrm{~A}$ & $14.7 \mathrm{~A}$ \\
\hline & & & $\mathrm{MBC}(\mathrm{mg}$ & & & \\
\hline $\mathrm{NT}_{\mathrm{M}}$ & $363.2 \mathrm{~B}$ & $197.7 \mathrm{AB}$ & $262.3 \mathrm{~B}$ & $262.3 \mathrm{~A}$ & $169.5 \mathrm{BC}$ & 223.1 \\
\hline $\mathrm{NT}_{\mathrm{MM}}$ & $400.5 \mathrm{AB}$ & $199.1 \mathrm{AB}$ & $322.6 \mathrm{~A}$ & $274.5 \mathrm{~A}$ & $219.1 \mathrm{~A}$ & 235.9 \\
\hline $\mathrm{RT}_{\mathrm{M}}$ & $305.2 \mathrm{C}$ & $238.1 \mathrm{~A}$ & $190.7 \mathrm{D}$ & $210.3 \mathrm{~A}$ & $173.4 \mathrm{BC}$ & 271.2 \\
\hline $\mathrm{RT}_{\mathrm{MM}}$ & $438.3 \mathrm{~A}$ & $146.8 \mathrm{~B}$ & $254.5 \mathrm{BC}$ & $262.3 \mathrm{~A}$ & 209.3 B & 207.7 \\
\hline $\mathrm{CT}_{\mathrm{M}}$ & $320.4 \mathrm{C}$ & $204.7 \mathrm{AB}$ & $251.2 \mathrm{C}$ & $264.3 \mathrm{~A}$ & $156.4 \mathrm{C}$ & 222.7 \\
\hline \multirow[t]{2}{*}{$\mathrm{CT}_{\mathrm{MM}}$} & $290.5 \mathrm{C}$ & $201.0 \mathrm{AB}$ & $281.6 \mathrm{AB}$ & $272.4 \mathrm{~A}$ & $210.4 \mathrm{AB}$ & 256.3 \\
\hline & & & $q$ Mic (\%) & & & \\
\hline $\mathrm{NT}_{\mathrm{M}}$ & 1.71 & 0.85 & 1.43 & 1.48 & 1.08 & 1.45 \\
\hline $\mathrm{NT}_{\mathrm{MM}}$ & 1.72 & 0.78 & 1.81 & 1.53 & 1.48 & 1.56 \\
\hline $\mathrm{RT}_{\mathrm{M}}$ & 1.36 & 1.04 & 1.12 & 1.16 & 1.14 & 1.65 \\
\hline $\mathrm{RT}_{\mathrm{MM}}$ & 2.00 & 0.64 & 1.55 & 1.50 & 1.41 & 1.39 \\
\hline $\mathrm{CT}_{\mathrm{M}}$ & 1.49 & 1.02 & 1.29 & 1.47 & 0.98 & 1.48 \\
\hline $\mathrm{CT}_{\mathrm{MM}}$ & 1.47 & 1.06 & 1.52 & 1.52 & 1.33 & 1.74 \\
\hline
\end{tabular}

(1) NT: no-tillage; RT: reduced tillage; CT: conventional tillage; M: maize monoculture; MM: maize-Mucuna aterrima intercrop. Means followed by the same letter in the column do not differ from each other by the Tukey test at $5 \%$. 


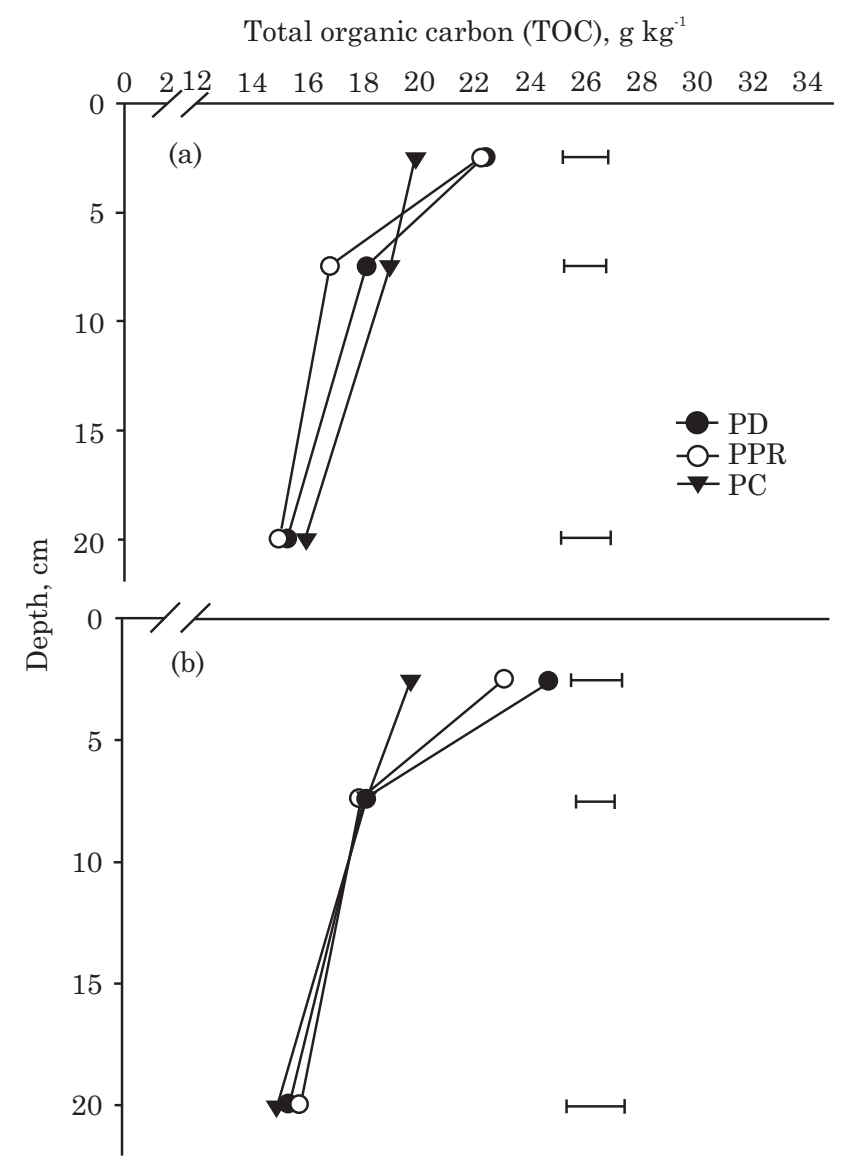

Figure 1. Total organic carbon (TOC) in Oxisol under different tillage systems, in summer (a) and winter sampling (b). NT, RT and CT are, respectively, no-tillage, reduced tillage and conventional tillage. The horizontal bars refer to the least significant difference (LSD) by the Tukey test $(\mathbf{p}<0.05)$.

The highest TOC levels resulted in a stimulation of the microbial biomass. Thus, the MBC levels were higher in the conservation systems (NT and RT), which can be explained by the greater sensitivity of microbial $\mathrm{C}$, which is affected positively by the higher accumulation of organic substrate and negatively by soil disturbance, as observed by several authors for Cerrado soils (Figueiredo et al., 2007, 2010; Silva et al., 2007; Carneiro et al., 2008, 2009; Cunha et al., 2011). In the summer, regardless of the cover crop, in the 0.0-0.05 m layer, the MBC levels in NT were on average $29 \%$, i.e., higher than under CT.

The maize-mucuna intercrop in the summer for straw formation for soil mulching increased the MBC contents in NT and RT at all depths and CT in the subsurface layers, compared to the systems using only the grass species as cover crop. According to Cardoso et al. (2009), this increase is related to the higher, continuous and varied input of organic substrates from the greater diversity of species and with different degrees of susceptibility to decay. In situations with increased input of organic residues in the soil and with high root amounts, the microbial biomass is stimulated, resulting in population growth and activity increase (Souza et al., 2010).

The lowest MBC values were found under CT in the 0.0-0.05 m layer, justified by the fact that soil disturbance induces higher decomposition rates of organic materials, reducing the substrate for microbial development, as already observed in an Oxisol in the Cerrado (Nunes et al., 2011). Similar results of the effect of soil management were reported by Kandeler et al. (1999), who found higher values of soil microbial biomass in areas under minimum and reduced tillage and a $50 \%$ increase in the $0.0-0.10 \mathrm{~m}$ layer, three years after the introduction of minimum tillage in areas under conventional cultivation. This reduction in TOC levels and consequently in microbial biomass decreases the soil quality under vegetable cultivation (Valarini et al., 2011).

In general, a stratification of MBC levels was found with decreasing values in deeper layers. Under notillage the MBC levels always decreased in depth. In the other systems, this reduction was crop-dependent (maize or maize-mucuna). This MBC stratification demonstrates the effect of organic matter accumulation in the surface and root action, favoring microbial proliferation.

The MBC fraction accounted for between 0.64 and $2.00 \% \mathrm{TOC}$, in agreement with results of Matias et al. (2009) and Pragana et al. (2012) in Yellow Latosol under soybean in the Cerrado region of Piauí; Nunes et al. (2011) in a field experiment with maize-soybean rotation, in the Cerrado of the Federal District; and Matoso et al. (2012) in Red-Yellow Latosol, under different land uses in Amazonia.

The highest MBC contents were observed in conservation tillage systems, indicating greater $\mathrm{C}$ availability to the soil microbiota, since the MBC:TOC ratio is an indicator of the availability of organic matter to microorganisms, and a high microbial ratio indicates that the organic matter is very active and prone to changes (Sampaio et al., 2008).

With regard to the oxidizable fractions, as there was no influence of the interaction soil tillage $\times$ cover crop on any of the fractions, the effect of cover crop was disregarded and only the effect of tillage systems on the oxidizable fractions of soil organic $\mathrm{C}$ was addressed (Table 4). In this study, the fractions were grouped according to their lability $(\mathrm{F} 1+\mathrm{F} 2)$ and recalcitrance (F3 + F4). For Majumder et al. (2008), the fractions $\mathrm{F} 1$ and $\mathrm{F} 2$ can be considered good indicators of sustainability of the system, while the $\mathrm{F} 4$ fraction is the most resistant in the soil. It is called "passive compartment" in SOM simulation models with a recycling time of up to 2,000 years (Chan et al., 2001). 
Table 4. Fractions of oxidizable carbon in soil of different tillage systems, soil layers and sampling times

\begin{tabular}{|c|c|c|c|c|}
\hline \multirow{3}{*}{ System $^{(1)}$} & \multicolumn{4}{|c|}{ Fraction of oxidizable carbon } \\
\hline & \multicolumn{2}{|c|}{$\mathrm{F} 1+\mathrm{F} 2$} & \multicolumn{2}{|c|}{$\mathrm{F} 3+\mathrm{F} 4$} \\
\hline & Summer & Winter & Summer & Winter \\
\hline & \multicolumn{4}{|c|}{$-\mathrm{g} \mathrm{kg}^{-1}$} \\
\hline & \multicolumn{4}{|c|}{$0.0-0.05 \mathrm{~m}$} \\
\hline NT & $13.4 \mathrm{~A}$ & $11.6 \mathrm{~A}$ & $8.9 \mathrm{~A}$ & $11.7 \mathrm{~A}$ \\
\hline $\mathrm{RT}$ & $13.6 \mathrm{~A}$ & $10.4 \mathrm{AB}$ & $8.7 \mathrm{~A}$ & $12.4 \mathrm{~A}$ \\
\hline $\mathrm{CT}$ & $11.6 \mathrm{~B}$ & $8.8 \mathrm{~B}$ & $8.3 \mathrm{~A}$ & $11.0 \mathrm{~A}$ \\
\hline & \multicolumn{4}{|c|}{$0.05-0.10 \mathrm{~m}$} \\
\hline NT & $10.6 \mathrm{AB}$ & $8.1 \mathrm{~A}$ & $7.6 \mathrm{~A}$ & $9.7 \mathrm{~A}$ \\
\hline $\mathrm{RT}$ & $9.7 \mathrm{~B}$ & $7.5 \mathrm{~A}$ & $7.2 \mathrm{~A}$ & $10.4 \mathrm{~A}$ \\
\hline $\mathrm{CT}$ & $11.2 \mathrm{~A}$ & $8.2 \mathrm{~A}$ & $7.8 \mathrm{~A}$ & $9.8 \mathrm{~A}$ \\
\hline & \multicolumn{4}{|c|}{$0.10-0.30 \mathrm{~m}$} \\
\hline NT & $8.7 \mathrm{~A}$ & $7.2 \mathrm{~A}$ & $6.6 \mathrm{~A}$ & $9.0 \mathrm{~A}$ \\
\hline $\mathrm{RT}$ & $9.4 \mathrm{~A}$ & $6.1 \mathrm{~A}$ & $5.6 \mathrm{~A}$ & $9.4 \mathrm{~A}$ \\
\hline $\mathrm{CT}$ & $9.8 \mathrm{~A}$ & $6.5 \mathrm{~A}$ & $6.2 \mathrm{~A}$ & $8.7 \mathrm{~A}$ \\
\hline
\end{tabular}

(1) NT: no-tillage; RT: reduced tillage; CT: conventional tillage; M: maize monoculture; MM: maize-Mucuna aterrima intercrop. Means followed by the same letter in the column do not differ from each other by the Tukey test at $5 \%$.

In the soil sampled in the summer, the $\mathrm{C}$ contents in the most labile fractions were between $8.7 \mathrm{~g} \mathrm{~kg}^{-1}$ in NT in the $0.10-0.30 \mathrm{~m}$ layer to $13.6 \mathrm{~g} \mathrm{~kg}^{-1}$ in RT in the 0.0-0.05 m layer. These amounts represented, on average, $50 \%$ of TOC, demonstrating that the labile and recalcitrant fractions of organic matter were similar in soil under vegetables in the different management systems. A similar behavior was observed by Rangel et al. (2008), who reported that the F1 fraction represented $30-50 \%$ of the TOC in the 0.0-0.10 m layer. This shows the presence of organic matter with higher bioavailability in the surface soil layer, which explains the higher MBC levels, in response to the increased amount of substrate with greater TOC availability in conservation tillage systems.

In the 0.0-0.05 $\mathrm{m}$ layer, the $\mathrm{C}$ content in the $\mathrm{CT}$ system was lowest $\left(11.6 \mathrm{~g} \mathrm{~kg}^{-1}\right)$ in the fractions $\mathrm{F} 1+$ F2, reflecting the influence of soil tillage on the degradation of easily oxidizable organic $\mathrm{C}$. In the intermediate layer (0.05-0.10 m), the C content in CT did not differ from that in NT but was higher than in RT, showing an inversion of layers due to soil tillage. This demonstrates that the influence of soil management systems is more significant in the upper soil layers.

The $\mathrm{C}$ content of the most stable fractions (F3 and F4) varied from 8.7 to $12.4 \mathrm{~g} \mathrm{~kg}^{-1}$, with no significant differences between soil depths, showing that the tillage system had little influence on the most recalcitrant fractions, due to their greater physical and chemical soil protection (Loss et al., 2010a).

In the humic acid fraction the $\mathrm{C}$ contents $\left(\mathrm{C}_{\mathrm{HA}}\right)$ ranged from 3.72 to $6.20 \mathrm{~g} \mathrm{~kg}^{-1}$. Effects of tillage system and cover crop on the HA levels were only observed in the summer sampling and in the surface layers (0.0-0.05 and 0.05-0.10 m) (Table 5). At that time, reduced tillage systems $\left(\mathrm{RT}_{\mathrm{M}}\right.$ and $\left.\mathrm{RT}_{\mathrm{MM}}\right)$ had lower HA levels than $\mathrm{NT}_{\mathrm{MM}}$ in the 0.0-0.05 m layer. This same pattern of superiority of $\mathrm{NT}_{\mathrm{MM}}$ was also observed in the 0.05-0.10 m layer. The $\mathrm{C}_{\mathrm{HA}}$ levels in this layer were also higher for maize-mucuna intercrop under reduced tillage than for maize monoculture, demonstrating the positive effect of intercropping on the SOM quality, reflecting positively on vegetable production. However, in the 0.10-0.30 m layer, no differences in humic fractions between the systems were observed. The $\mathrm{C}$ content in the fulvic acid fraction $\left(\mathrm{C}_{\mathrm{FA}}\right)$ ranged from 2.88 in $\mathrm{RT}_{\mathrm{M}}$ in the $0.05-0.10 \mathrm{~m}$ layer in the winter to $4.31 \mathrm{~g} \mathrm{~kg}^{-1}$ in $\mathrm{NT}_{\mathrm{M}}$, in the same layer in the summer, as similarly reported by Fontana et al. (2006). No differences were detected between the systems in any of the soil layers.

In the humin fraction, the $\mathrm{C}$ levels $\left(\mathrm{C}_{\mathrm{HUM}}\right)$ varied from 6.19 in $\mathrm{NT}_{\mathrm{MM}}$ in the winter to $12.25 \mathrm{~g} \mathrm{~kg}^{-1}$ in the $\mathrm{NT}_{\mathrm{M}}$ in the summer, both in the 0.05-0.10 m layer. The $\mathrm{C}_{\mathrm{HUM}}$ accounted for the greatest portion of TOC, as also observed by Barreto et al. (2008) and Loss et al. (2010b). This predominance of $\mathrm{C}_{\mathrm{HUM}}$ is related to its insolubility and resistance to biodegradation, favored by the formation of stable clay-humic complexes (Fontana et al., 2006).

In the winter sampling, the $\mathrm{C}_{\mathrm{FA}}$ levels differed between management systems in the 0.05-0.10 m layer only, with higher content in $\mathrm{CT}_{\mathrm{M}}\left(3.68 \mathrm{~g} \mathrm{~kg}^{-1}\right)$ than in $\mathrm{RT}_{\mathrm{M}}\left(2.88 \mathrm{~g} \mathrm{~kg}^{-1}\right)$.

In soil collected from the tillage systems in summer, independently of the cover crop, the $\mathrm{C}_{\mathrm{HUM}}$ levels in the treatments NT and RT were higher than in $\mathrm{CT}$ in the two upper layers. In all three soil management systems, higher $\mathrm{C}_{\mathrm{HUM}}$ levels were observed in the 0.05-0.10 m layer. In the deepest layer, no differences were observed between tillage systems (Figure 2a). In the winter sampling of the systems, the $\mathrm{C}_{\mathrm{HUM}}$ levels did not differ between layers (Figure 2b).

Despite the absence of statistical differences between the sampling times, the $\mathrm{C}$ contents of the humic substances, especially in the humin fraction, were on average higher in summer than in winter. This pattern may be due to the greater input of plant residues from maize or maize and mucuna straw, with higher temperatures and water availability in this season. These conditions favor the decomposition of these residues for the subsequent formation of humic substances, as similarly observed by Silva et al. (2006) and Loss et al. (2010b). 
Table 5. Carbon of humic fractions in soil of different management systems, cover species, layers and sampling times

\begin{tabular}{|c|c|c|c|c|c|c|}
\hline \multirow{2}{*}{ System $^{(1)}$} & \multicolumn{2}{|c|}{ Humic acid } & \multicolumn{2}{|c|}{ Fulvic acid } & \multicolumn{2}{|c|}{ Humin } \\
\hline & Summer & Winter & Summer & Winter & Summer & Winter \\
\hline & \multicolumn{6}{|c|}{$\mathrm{g} \mathrm{kg}^{-1}$} \\
\hline & \multicolumn{6}{|c|}{$0.0-0.05 \mathrm{~m}$} \\
\hline $\mathrm{NT}_{\mathrm{M}}$ & $4.73 \mathrm{AB}$ & $4.55 \mathrm{~A}$ & $3.39 \mathrm{~A}$ & $3.39 \mathrm{~A}$ & $10.82 \mathrm{~A}$ & $8.52 \mathrm{~A}$ \\
\hline $\mathrm{NT}_{\mathrm{MM}}$ & $5.52 \mathrm{~A}$ & $5.02 \mathrm{~A}$ & $3.99 \mathrm{~A}$ & $3.55 \mathrm{~A}$ & $11.02 \mathrm{~A}$ & $8.55 \mathrm{~A}$ \\
\hline $\mathrm{RT}_{\mathrm{M}}$ & $4.07 \mathrm{~B}$ & $4.99 \mathrm{~A}$ & $3.45 \mathrm{~A}$ & $3.47 \mathrm{~A}$ & $11.46 \mathrm{~A}$ & $9.43 \mathrm{~A}$ \\
\hline $\mathrm{RT}_{\mathrm{MM}}$ & $4.03 \mathrm{~B}$ & $4.57 \mathrm{~A}$ & $3.42 \mathrm{~A}$ & $3.83 \mathrm{~A}$ & $11.32 \mathrm{~A}$ & $9.48 \mathrm{~A}$ \\
\hline $\mathrm{CT}_{\mathrm{M}}$ & $4.27 \mathrm{AB}$ & $5.16 \mathrm{~A}$ & $3.37 \mathrm{~A}$ & $3.69 \mathrm{~A}$ & $8.92 \mathrm{~A}$ & $8.59 \mathrm{~A}$ \\
\hline \multirow[t]{2}{*}{$\mathrm{CT}_{\mathrm{MM}}$} & $4.57 \mathrm{AB}$ & $4.68 \mathrm{~A}$ & $3.85 \mathrm{~A}$ & $3.53 \mathrm{~A}$ & $9.00 \mathrm{~A}$ & $9.00 \mathrm{~A}$ \\
\hline & \multicolumn{6}{|c|}{$0.05-0.10 \mathrm{~m}$} \\
\hline $\mathrm{NT}_{\mathrm{M}}$ & $5.32 \mathrm{ABC}$ & $4.54 \mathrm{~A}$ & 4.31 & $3.49 \mathrm{AB}$ & $12.25 \mathrm{~A}$ & $6.90 \mathrm{~A}$ \\
\hline $\mathrm{NT}_{\mathrm{MM}}$ & $6.20 \mathrm{~A}$ & $3.72 \mathrm{~A}$ & 4.13 & $3.03 \mathrm{AB}$ & $12.13 \mathrm{~A}$ & $6.19 \mathrm{~A}$ \\
\hline $\mathrm{RT}_{\mathrm{M}}$ & $4.60 \mathrm{C}$ & $3.81 \mathrm{~A}$ & 3.52 & $2.88 \mathrm{~B}$ & $11.83 \mathrm{~A}$ & $7.52 \mathrm{~A}$ \\
\hline $\mathrm{RT}_{\mathrm{MM}}$ & $5.64 \mathrm{~B}$ & $4.55 \mathrm{~A}$ & 4.29 & $3.03 \mathrm{AB}$ & $12.00 \mathrm{~A}$ & $6.22 \mathrm{~A}$ \\
\hline $\mathrm{CT}_{\mathrm{M}}$ & $5.76 \mathrm{AB}$ & $4.44 \mathrm{~A}$ & 3.75 & $3.68 \mathrm{~A}$ & $9.49 \mathrm{~B}$ & $7.01 \mathrm{~A}$ \\
\hline \multirow[t]{2}{*}{$\mathrm{CT}_{\mathrm{MM}}$} & $5.48 \mathrm{ABC}$ & $4.22 \mathrm{~A}$ & 3.75 & $3.19 \mathrm{AB}$ & $9.02 \mathrm{~B}$ & $7.09 \mathrm{~A}$ \\
\hline & \multicolumn{6}{|c|}{$0.10-0.30 \mathrm{~m}$} \\
\hline $\mathrm{NT}_{\mathrm{M}}$ & $4.52 \mathrm{~A}$ & $4.60 \mathrm{~A}$ & $3.25 \mathrm{~A}$ & $3.52 \mathrm{~A}$ & $8.83 \mathrm{~A}$ & $7.69 \mathrm{~A}$ \\
\hline $\mathrm{NT}_{\mathrm{MM}}$ & $4.56 \mathrm{~A}$ & $4.42 \mathrm{~A}$ & $3.06 \mathrm{~A}$ & $3.36 \mathrm{~A}$ & $8.25 \mathrm{~A}$ & $6.64 \mathrm{~A}$ \\
\hline $\mathrm{RT}_{\mathrm{M}}$ & $3.72 \mathrm{~A}$ & $4.04 \mathrm{~A}$ & $2.97 \mathrm{~A}$ & $3.30 \mathrm{~A}$ & $8.89 \mathrm{~A}$ & $7.23 \mathrm{~A}$ \\
\hline $\mathrm{RT}_{\mathrm{MM}}$ & $4.36 \mathrm{~A}$ & $4.05 \mathrm{~A}$ & $3.22 \mathrm{~A}$ & $3.84 \mathrm{~A}$ & $7.65 \mathrm{~A}$ & $8.68 \mathrm{~A}$ \\
\hline $\mathrm{CT}_{\mathrm{M}}$ & $4.53 \mathrm{~A}$ & $4.22 \mathrm{~A}$ & $3.11 \mathrm{~A}$ & $3.60 \mathrm{~A}$ & $8.72 \mathrm{~A}$ & $6.90 \mathrm{~A}$ \\
\hline $\mathrm{CT}_{\mathrm{MM}}$ & $4.73 \mathrm{~A}$ & $4.57 \mathrm{~A}$ & $3.40 \mathrm{~A}$ & $3.99 \mathrm{~A}$ & $7.59 \mathrm{~A}$ & $6.90 \mathrm{~A}$ \\
\hline
\end{tabular}

(1) NT: no-tillage; RT: reduced tillage; CT: conventional tillage; M: maize monoculture; MM: maize-Mucuna aterrima intercrop. Means followed by the same letter in the column do not differ from each other by the Tukey test at $5 \%$.

Evaluating only the tillage systems, disregarding the straw used to cover the soil, the $\mathrm{C}_{\mathrm{HA}} / \mathrm{C}_{\mathrm{FA}}$ index was between 1.16 and 1.50 , similar to the values reported by Cunha et al. (2005) and Pessoa et al. (2012) and higher than those found by Lima (2001). This range indicates that the low-solubility fraction $\left(\mathrm{C}_{\mathrm{HA}}\right)$, usually related to a higher condensation of humic compounds (Cunha et al., 2005), was predominant. A $\mathrm{C}_{\mathrm{HA}} / \mathrm{C}_{\mathrm{FA}}$ ratio higher than 1 is an indicator of the predominance of organic matter of better quality (Cunha et al., 2005), which is essential for vegetable production.

The mean cabbage yield ranged from 78,908 to $90,440 \mathrm{~kg} \mathrm{ha}^{-1}$ (Table 6). Although the differences among tillage systems were not significant when evaluating only the factor cover crop, the mean yield on the maize-mucuna intercrop plots was higher $\left(85,611 \mathrm{~kg} \mathrm{ha}^{-1}\right)$ than on the summer crop plots with maize monoculture $\left(79,334 \mathrm{~kg} \mathrm{ha}^{-1}\right)$. The use of legume-grass intercrops is a management strategy that not only protects the soil and supplies $\mathrm{N}$, but also provides dry matter production with intermediate $\mathrm{C} / \mathrm{N}$, reducing the decomposition rate of crop residues and synchronizing $\mathrm{N}$ supply and demand of the crop (Aita \& Giacomini, 2003; Giacomini et al., 2003; Carvalho et al., 2011, 2012).

Table 6. Cabbage yield under different tillage systems and cover crops

\begin{tabular}{lc}
\hline System $^{(1)}$ & Yield \\
\hline & $\mathrm{kg} \mathrm{ha}^{-1}$ \\
$\mathrm{NT}_{\mathrm{M}}$ & $78,908 \mathrm{~A}$ \\
$\mathrm{NT}_{\mathrm{MM}}$ & $83,476 \mathrm{~A}$ \\
$\mathrm{RT}_{\mathrm{M}}$ & $79,651 \mathrm{~A}$ \\
$\mathrm{RT}_{\mathrm{MM}}$ & $90,440 \mathrm{~A}$ \\
$\mathrm{CT}_{\mathrm{M}}$ & $79,444 \mathrm{~A}$ \\
$\mathrm{CT}_{\mathrm{MM}}$ & $82,817 \mathrm{~A}$ \\
$\mathrm{Cover}_{\text {plant }}{ }^{(2)}$ & \\
maize & $79,334 \mathrm{~B}$ \\
maize and mucuna & $85,611 \mathrm{~A}$ \\
\hline
\end{tabular}

(1) NT: no-tillage; RT: reduced tillage; CT: conventional tillage; M: maize monoculture; MM: maize-Mucuna aterrima intercrop. (2) Mean yield, independent of soil tillage. Means followed by the same letter in the column do not differ from each other by the Tukey test at $5 \%$. 
Carbon of the humin fraction $\left(\mathrm{C}_{\mathrm{HUM}}\right), \mathrm{g} \mathrm{kg}^{-1}$

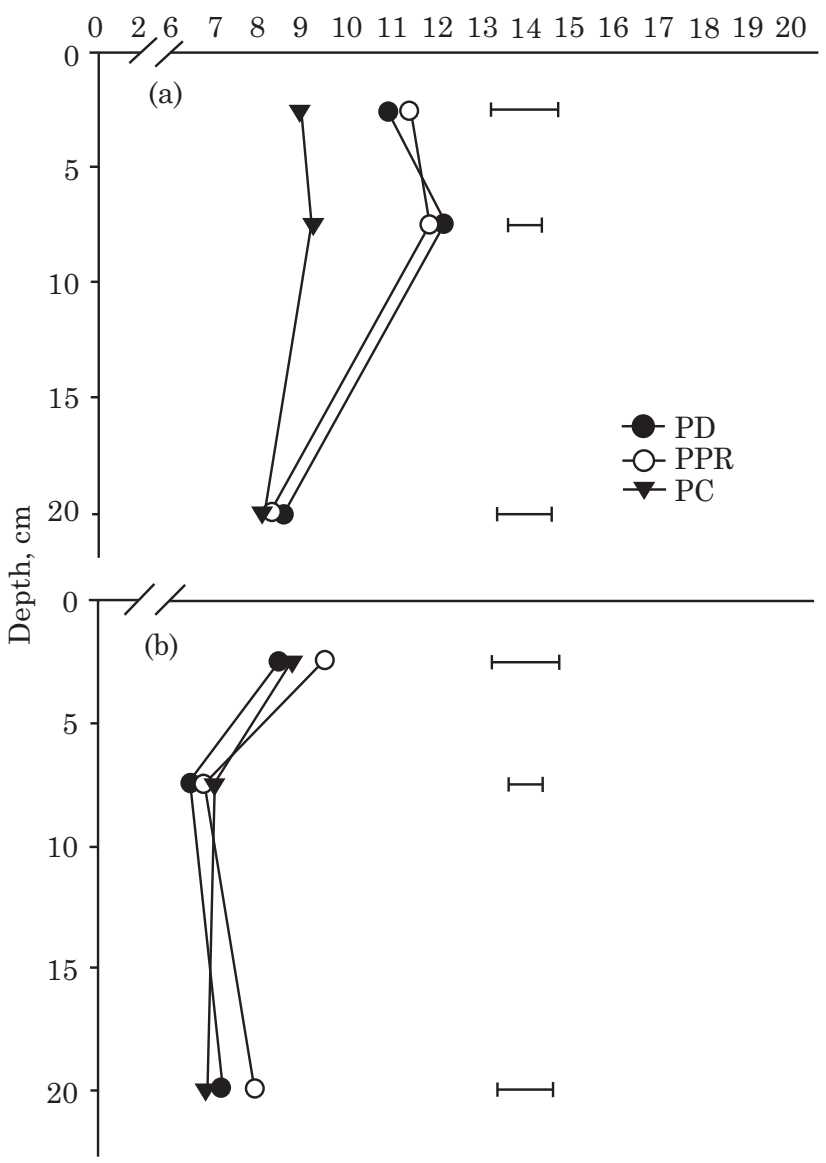

Figure 2. Carbon of the humin fraction $\left(\mathrm{C}_{\mathrm{HUM}}\right)$ in Oxisol under different soil tillage systems, in summer (a) and winter sampling (b). NT, RT and CT are, respectively, no-tillage, reduced tillage and conventional tillage. The horizontal bars refer to the least significant difference (LSD) by the Tukey test $(\mathbf{p}<0.05)$.

\section{CONCLUSIONS}

1. No-tillage vegetable production tended to increase the more labile and more easily oxidizable organic matter fractions, mainly in the upper layers.

2. Humic fractions were influenced by soil management in the surface layers only, and no-tillage with mucuna resulted in higher levels of humic acids and conventional tillage in higher levels of fulvic acids than the system with reduced tillage.

3 . The $\mathrm{C}$ contents of the humin fraction in the 0.05-0.10 m layer were lowest in the conventional system of vegetable cultivation.

4. Regardless of the management system, the use of maize-mucuna intercrop as summer crop resulted in higher cabbage production.

\section{ACKNOWLEDGEMENT}

The authors wish to thank the Coordination of Improvement of Higher Education Personnel (CAPES) for a scholarship to the first author.

\section{LITERATURE CITED}

AITA, C. \& GIACOMINI, S.J. Decomposição e liberação de nitrogênio de resíduos culturais de plantas de cobertura de solo solteiras e consorciadas. R. Bras. Ci. Solo, 27:601$612,2003$.

AMADO, T.J.C.; BAYER, C.; ELTZ, F.L.F. \& BRUM, A.C.R. Potencial de culturas de cobertura em acumular carbono e nitrogênio no solo no plantio direto e a melhoria da qualidade ambiental. R. Bras. Ci. Solo, 25:189-197, 2001.

BALOTA, E.L.; COLOZZI-FILHO, A.; ANDRADE, D.S. \& HUNGRIA, M. Biomassa microbiana e sua atividade em solos sob diferentes sistemas de preparo e sucessão de culturas. R. Bras. Ci. Solo, 22:641-649, 2008.

BARRETO, A.C.; FREIRE, M.B.G.S.; NACIF, G.S.; ARAÚJO, Q.R.; FREIRE, F.F. \& INÁCIO, E.S.B. Fracionamento químico e físico do carbono orgânico total em um solo de mata submetido a diferentes usos. R. Bras. Ci. Solo, $32: 1471-1478,2008$.

BAYER, C.; MARTIN-NETO, L.; MIELNICZUK, J. \& PAVINATO, A. Armazenamento de carbono em frações lábeis da matéria orgânica de um Latossolo Vermelho sob plantio direto. Pesq. Agropec. Bras., 39:677-683, 2004.

BLAIR, G.J.; LEFROY, R.D.B. \& LISLE, L. Soil carbon fractions based on their degree of oxidation, and the development of a carbon management index for agricultural systems. Aust. J. Agric. Res., 46:1459-1466, 1995.

CARDOSO, E.L.; SILVA, M.L.N.; MOREIRA, F.M.S. \& CURI, $\mathrm{N}$. Atributos biológicos indicadores da qualidade do solo em pastagem cultivada e nativa no Pantanal. Pesq. Agropec. Bras., 44:631-637, 2009.

CARNEIRO, M.A.C.; SIQUEIRA, J.O.; MOREIRA, F.M.S. \& SOARES, A.L.L. Carbono orgânico, nitrogênio total, biomassa e atividade microbiana do solo em duas cronossequências de reabilitação após a mineração de bauxita. R. Bras. Ci. Solo, 32:621-632, 2008.

CARNEIRO, M.A.C.; SOUZA, E.D.; REIS, E.F.; PEREIRA, H.S. \& AZEVEDO, W.R. Atributos físicos, químicos e biológicos de solo de Cerrado sob diferentes sistemas de uso e manejo. R. Bras. Ci. Solo, 33:147-157, 2009.

CARVALHO, A.M.; COELHO, M.C.; DANTAS, R.A.; FONSECA, O.P.; GUIMARÃES JÚNIOR, R. \& FIGUEIREDO, C.C. Chemical composition of cover plants and its effect on maize yield in no-tillage systems in the Brazilian savanna. Crop Past. Sci., 63:1075-1081, 2012.

CARVALHO, A.M.; SOUZA, L.L.P.; GUIMARÃES JÚNIOR, R.; ALVES, P.C.A.C. \& VIVALDI, J.L. Cover plants with potential use for crop-livestock integrated systems in the Cerrado region. Pesq. Agropec. Bras., 26:1200-1205, 2011. 
CARVALHO, J.L.N.; AVANZI, J.C.; SILVA, M.L.N.; MELLO, C.R. \& CERRI, C.E.P. Potencial de sequestro de carbono em diferentes biomas do Brasil. R. Bras. Ci. Solo, 34:277$289,2010$.

CHAN, K.Y.; BOWMAN, A. \& OATES, A. Oxidizidable organic carbon fractions and soil quality changes in an Oxic Paleustalf under different pasture ley. Soil Sci., 166:6167, 2001.

CUNHA, T.J.F.; MACEDO, J.R.; RIBEIRO, L.P.; PALMIERI, F.; FREITAS, P.L. \& AGUIAR, A.C. Impacto do manejo convencional sobre propriedades físicas e substâncias húmicas de solos sob cerrado. Ci. Rural, 31:27-36, 2001.

CUNHA, E.Q.; STONE, L.F.; FERREIRA, E.P.B.; DIDONET, A.D.; MOREIRA, J.A.A. \& LEANDRO, W.M. Sistemas de preparo do solo e culturas de cobertura na produção orgânica de feijão e milho. II - Atributos biológicos do solo. R. Bras. Ci. Solo, 35:603-611, 2011.

CUNHA, T.J.F.; CANELAS, L.P.; SANTOS, G.A. \& RIBEIRO, L.P. Fracionamento da matéria orgânica humificada em solos brasileiros In: CANELLAS, L.P. \& SANTOS, G.A., orgs. Humosfera. Campos dos Goitacazes, UENF, 2005. p.54-80.

EMPRESA BRASILEIRA DE PESQUISA AGROPECUÁRIA - EMBRAPA. Centro Nacional de Pesquisa de Solos. Manual de métodos de análise de solo. 2. ed. Rio de Janeiro, 1997. 212p.

FERREIRA, A.S.; CAMARGO, F.A.O. \& VIDOR, C. Utilização de microondas na avaliação da biomassa microbiana do solo. R. Bras. Ci. Solo, 23:991-996, 1999.

FIGUEIREDO, C.C.; RESCK, D.V.S. \& CARNEIRO, M.A. Carbon labile and stable fractions of soil organic matter under management systems and native Cerrado. R. Bras. Ci. Solo, 34:907-916, 2010.

FIGUEIREDO, C.C.; RESCK, D.V.S.; GOMES, A.C.; FERREIRA, E.A.B. \& RAMOS, M.L.G. Carbono e nitrogênio da biomassa microbiana em resposta a diferentes sistemas de manejo em um Latossolo Vermelho no Cerrado. R. Bras. Ci. Solo, 31:551-562, 2007.

FILGUEIRA, F.A.R. Novo manual de olericultura: Agrotecnologia moderna na produção e comercialização de hortaliças. Viçosa, MG, Universidade Federal de Viçosa, 2000. 402p.

FONTANA, A.; PEREIRA, M.G.; LOSS, A.; CUNHA, T.J.F. \& SALTON, J.C. Atributos de fertilidade e frações húmicas de um Latossolo Vermelho no Cerrado. Pesq. Agropec. Bras., 41:847-853, 2006.

GIACOMINI, S.J.; AITA, C.; VENDRUSCULO, E.R.O.; CUBILlA, M.; NICOLOSO, R.S. \& FRIES, M.R. Decomposição e liberação de nitrogênio de resíduos culturais de plantas de cobertura de solo solteiras e consorciadas. R. Bras. Ci. Solo, 27:601-612, 2003.

GUARESCHI, R.F.; PEREIRA, M.G. \& PERIN, A. Deposição de resíduos vegetais, matéria orgânica leve, estoques de carbono e nitrogênio e fósforo remanescente sob diferentes sistemas de manejo no cerrado goiano. R. Bras. Ci. Solo, 36:909-920, 2012.
KANDELER, E.; TSCHERKO, D. \& SPIEGEL, H. Long-term monitoring of microbial biomass, $\mathrm{N}$ mineralization and enzyme activities of a Chernozem under different tillage management. Biol. Fertil. Soils, 28:343-351, 1999.

LIMA, H.N. Gênese, química, mineralogia e micromorfologia de solos da Amazônia Ocidental. Viçosa, MG, Universidade Federal de Viçosa, 2001. 176p. (Tese de Doutorado)

LOSS, A.; MORAES, A.G.L.; PEREIRA, M.G.; SILVA, E.M.R. \& ANJOS, L.H.C. Carbono, matéria orgânica leve e frações oxidáveis do carbono orgânico sob diferentes sistemas de produção orgânica. Com. Sci., 1:57-64, 2010a.

LOSS, A.; PEREIRA, M.G.; SCHULTZ, N.; ANJOS, L.H.C. \& SILVA, E.M.R. Quantificação do carbono das substâncias húmicas em diferentes sistemas de uso do solo e épocas de avaliação. Bragantia, 69:913-922, 2010b.

MAJUMDER, B.; MANDAL, B.; BANDYOPADHYAY, K.; GANGOPADHYAY, A.; MANI, K.; KUNDU, A.L. \& MAZUMDAR, D. Organic amendments influence soil organic carbon pools and rice-wheat productivity. Soil Sci. Soc. Am. J., 72:775-785, 2008.

MATIAS, M.C.B.S.; SALVIANO, A.A.C.; LEITE, L.F.C. \& ARAÚJO, A.S.F. Biomassa microbiana e estoques de C e $\mathrm{N}$ do solo em diferentes sistemas de manejo, no Cerrado do Estado do Piauí. Acta Sci. Agron., 31:517-521, 2009.

MATOSO, S.C.G.; SILVA, A.N.; FIORELLI-PEREIRA, E.C.; COLLETA, Q.P. \& MAIA, E. Frações de carbono e nitrogênio de um Latossolo Vermelho-Amarelo distrófico sob diferentes usos na Amazônia brasileira. Acta Amaz., 42:231-240, 2012.

MENDONÇA, E.S. \& MATOS, E.S. Matéria orgânica do solo: métodos de análises. Viçosa, MG, Universidade Federal de Viçosa, 2005. 107p.

MENEZES, R.S.C. \& SILVA, T.O. Mudanças na fertilidade de um Neossolo Regolítico após seis anos de adubação orgânica. R. Bras. Eng. Agric. Amb., 12:251-257, 2008.

NUNES, R.S.; LOPES, A.L.C.; SOUSA, D.M.G. \& MENDES, I.C. Sistemas de manejo e os estoques de carbono e nitrogênio em Latossolo de Cerrado com a sucessão sojamilho. R. Bras. Ci. Solo, 35:1407-1419, 2011.

PEREIRA, M.G.; LOSS, A.; BEUTLER, S.J. \& TORRES, J.L.R. Carbono, matéria orgânica leve e fósforo remanescente em diferentes sistemas de manejo do solo. Pesq. Agropec. Bras., 45:508-514, 2010.

PESSOA, M.A.; DUDA, G.P.; BARROS, R.B.; FREIRE, M.B.G.S.; NASCIMENTO, C.W.A. \& CORREA, M.M. Frações de carbono orgânico de um Latossolo húmico sob diferentes usos no agreste brasileiro. R. Bras. Ci. Solo, 36:97-104, 2012

PORTUGAL, A.F.; JUCKSCH, I. \& SCHAEFER, C.E.G.R. Determinação de estoques total de carbono e nitrogênio e suas frações em sistemas agrícolas implantados em Argissolo Vermelho-Amarelo. R. Bras. Ci. Solo, 32:2091-2100, 2008.

PRAGANA, R.B.; NÓBREGA, R.S.A.; RIBEIRO, M.R. \& LUSTOSA FILHO, J.F. Atributos biológicos e dinâmica da matéria orgânica em Latossolos Amarelos na região do Cerrado piauiense sob sistema plantio direto. R. Bras. Ci. Solo, 36:851-858, 2012. 
RANGEL，O.J.P.; SILVA，C.A.; GUIMARÃES，T.G. \& GUILHERME, L.R.G. Frações oxidáveis do carbono orgânico de Latossolo cultivado com cafeeiro em diferentes espaçamentos de plantio. Ci. Agrotec., 32:429-437, 2008.

ROSA, C.M.; CASTILHOS, R.M.V.; DICK, D.P.; PAULETTO, E.A. \& GOMES, A.S. Teor e qualidade de substâncias húmicas de Planossolo sob diferentes sistemas de cultivo. Ci. Rural, 38:1589-1595, 2008.

SAMPAIO, D.B.; ARAÚJO, A.S.F. \& SANTOS, B. Avaliação de indicadores biológicos de qualidade do solo sob sistemas de cultivo convencional e orgânico de frutas. Ci. Agrotec., 32:353-359, 2008.

SANTANA, G.S.; DICK, D.P.; JACQUES, A.V.A. \& CHITARRA, G.S. Substâncias húmicas e suas interações com $\mathrm{Fe}$ e $\mathrm{Al}$ em Latossolo subtropical sob diferentes sistemas de manejo de pastagem. R. Bras. Ci. Solo, 35:461-472, 2011.

SANTOS, H.G.; JACOMINE, K.T.; ANJOS, L.H.C.; OLIVEIRA, A.; OLIVEIRA, J.B.; COELHO, M.R.; LUMBRERAS, J.F. \& CUNHA, T.J.F., eds. Sistema brasileiro de classificação de solos. 2.ed. Rio de Janeiro, Embrapa Solos, 2006. 306p.
SAS Institute. Statistical Analysis System. Getting started with the SAS Learning Edition. Cary, 2002. 86p.

SILVA, C.F.; LOSS, A.; SILVA, E.M.R.; PEREIRA, M.G. \& CORREIA, M.E.F. Alterações químicas e físicas em áreas de agricultura no entorno do parque Estadual da Serra do Mar, Ubatuba-SP. R. Ci. Agrár., 46:9-28, 2006.

SILVA, M.B.; KLIEMANN, H.J.; SILVEIRA, M. \& LANNA, A.C. Atributos biológicos do solo sob influência da cobertura vegetal e do sistema de manejo. Pesq. Agropec. Bras., 42:1755-1761, 2007.

SOUZA, E.D.; COSTA, S.E.V.D.G.; ANGHINONI, I.; LIMA, C.V.S.; CARVALHO, C.S. \& MARTINS, A.P. Biomassa microbiana do solo em sistema de integração lavourapecuária em plantio direto, submetido a intensidades de pastejo. R. Bras. Ci. Solo, 34:79-88, 2010.

STEVENSON, F.J. Humus chemistry: Genesis, composition, reactions. 2.ed. New York, John Willey, 1994. 496p.

VALARINI, P.J.; OLIVEIRA, F.R.A.; SCHILICKMANN S.F. \& POPPI, R.J. Qualidade do solo em sistemas de produção de hortaliças orgânico e convencional. Hortic. Bras., 29:485-491, 2011. 